\title{
BULGARIAN INTELLECTUALS IN THE MIRROR OF THEIR COLLECTIVE PUBLIC POSITIONS (2005-2019)
}

Katia Mihailova $^{1}$

\section{Introduction}

Intellectuals' public collective positions, expressed as open letters and invocations, declarations, petitions and manifests, more than a century - from Emil Zola's open letter "J'Accuse...!" in 1898 to the Open Letter of European intellectuals concerned about the future of Europe in 2019 (Lévy et al., 2019) - are often used as a tool for shaping public attitudes and overturning public opinion. Ivailo Znepolski speaks of overproduction of Bulgarian intellectuals' collective public positions after 1989, and even of war on petitions in the 1990s, leading to the slow (self)depersonalization of intellectuals (Znepolski, 2014).

In the meso-perspective, the intellectuals' public collective positions are a documentary, factual expression of the fundamental characteristic of the definition of intellectuals - their public commitment, their commitment to political, economic, cultural and religious transformations in society. The act of declaring and asserting a position on public issues, intervening in the political field on behalf of autonomy and the specific values of the field of cultural production that Zola did in the context of the Dreyfus Affair, is at the heart of the invention of the intellectual (Bourdieu, 1996). Once invented, the intellectual remains faithful to this distinctive feature to this day. We see its manifestation in Habermas' initiative "The May $31^{\text {st }}$ Action", within which a group of renowned European intellectuals have published their stances on the common European foreign policy and the role of Europe on the map of the world in articles in influential national media in 2003. The 2017 Paris Statement of a Conservative European Intellectuals Group, "A Europe we can believe in", is an expression of intellectual anxiety about the dissipation of Europe's civilization heritage, a call to reject the "fantasy utopia for a multicultural world without borders" and a "responsible alternative" (Paris Statement, 2017).

Public engagement is a fundamental definitive marker of intellectuals in the theory of sociology of intellectuals and in the proposal of its successor today the so-called sociology of interventions. Whether it is theorized on the notion of intelligentsia, people of knowledge and ideas, producers of culture, new class,

\footnotetext{
${ }^{1}$ Katia Mihailova, $\mathrm{PhD}$ in Journalism and Mass Communication, Assoc. Prof. of sociology, Department of Economic Sociology, UNWE, email: katiamihail@gmail.com
} 
intellectuals, opinion leaders, public intellectuals, leaders of thought, the condition of public engagement and position is invariable. It is even present in the works of writers like Bauman, according to whom every definition of intellectuals is a self-definition of ourselves that makes the question who the intellectuals are meaningless (Bauman, 1987).

The study presents the results of the second stage of the research of Bulgarian intellectuals' public collective positions, expressed in 2005-2019. The focus is not on the functions and patterns of positions' use in today's hybrid war, but on the information they contain about the Bulgarian intellectuals at the dawn of the new millennium. The research questions are what is the image of the Bulgarian intellectual in the mirror of the collective public positions and to what extent this image corresponds to the theoretical idea of the role and social functions of the intellectual. As each work is a mirror of its author, it is expected that the public collective positions of intellectuals should reflect information about themselves.

The results of the first stage of the study, which analyzed the collective positions of Bulgarian intellectuals expressed in 2005-2018, are presented in a previous study. It has raised the question of the formation and existence of an intellectual community and an intellectual elite in Bulgaria after 1989 (Mihailova, 2018).

\section{Methodological notes}

The content of 69 publicly expressed collective positions of Bulgarian intellectuals, recruited by media monitoring of Internet media have been analyzed. The research sample is presented in Table 1 below the text of the study. The media monitoring was performed by keyword search on Google between October 1, 2018 - May 30, 2019. Two active one-month monitoring phases were completed - the first October-November 2018, when 52 units were recruited and the second - April-May 2019 - which added another 17 units to the sample. The search has been done through single and double keywords: "intellectuals", "public figures", "professors", "citizens", "writers", "university lecturers" to each of them are added: "petition", "call", "subscription", "address", "support", "against". The first 100 hits on each of key words have been checked.

It should be noted that Google found numerous results by keyword "petition". All of them testify to the intensive use of the "petition" as a tool in asserting a position or solving a case of public concern. A quick review of the petitions shows two types among these according to their initiators:

(1) civil petitions most often for defending local and ecological positions, labor and civil rights, cultural and civilization achievements, and

(2) political petitions initiated by political figures or organizations to defend specific political demands and insistences. 
These two kinds of petitions are excluded from the research sample, as far as the research is focused on public positions of intellectuals.

Intellectuals are citizens as well, even in the last "Open Letter to Bulgarian Citizens on the celebration of the Bulgarian culture and the elections for the European Parliament" of 22 May 2019 [1] $^{1}$ the signatories define themselves as "citizens". The Open Letter is included in the sample after a review of the signatories, showing the connection of most of them with the intellectual field, at least because the names also appear in other intellectuals' activities. In addition, the media promoting the letter described it as a letter of intellectuals, not of citizens. The same self-determination as citizens and media definition as intellectuals occurs also in other units of the sample. It focuses on essential characteristics in the intellectuals, which is the subject of the research. Table 2 (below the text of the study) presents the distribution of the sample according to the addressing of petitions - initiators and addressees.

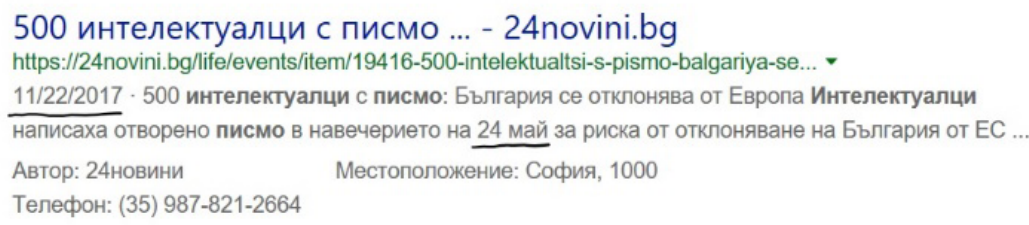

Fig. 1. A missmatch of the petition and media publication date

Each of the detected units before being sampled was subject to an authenticity check required by the streams of fake news flooding the space of the digital media. This is done by checking the unit's publications in three media, not only distributed over the Internet, but also traditional - print, radio, television. Media publications are also analyzed in terms of how they present the initiative. The public dialogue on the unit is also followed. A logical view of the content is made. The date of the position (letter, petition) and the date of its publication are set. It turned out that the two dates are different. The example in Figure 1 shows the publication date six months before the actual posting date. This discrepancy can be attributed to a number of factors and it is a warning sign for internet communication researchers.

The sample also includes a "fake" petition of intellectuals, which is claimed to have been signed by 100 "intellectuals and professors" while the actual signature is only one. It is about the petition "in connection with the erosion of the national substance", called by the author "bloody petition". It was published on 27 March 2015 by Deutsche Welle Bulgaria [31]. The fake petition is included as far as it

\footnotetext{
${ }^{1}$ Indicates the number of the public position in Table 1. Research Sample - applied after the end of the study.
} 
presents a frankly declared satirical replica of the petition activity of Bulgarian intellectuals and as such may serve as a counterpoint to the analysis.

If such monitoring is done through a software product for media monitoring in the Internet, it is possible that the list of public collective positions of Bulgarian intellectuals would be longer and more accurate and would certainly provide additional empirical information that would allow new analytical perspectives. For example, the relationship between positions and the media could be outlined or what media whose positions are spreading, and this in turn gives an insight into the nucleus of symbolic power in Bulgaria. In the current sample, the oldest public position is in 2005, which does not mean that intellectuals do not have such activity before the year, but that through Google's search capabilities and checking the first 100 hits, it is the farthest discovered publication. In this line, the research does not offer the dynamics of public interventions of intellectuals in public life based on their collective positions, but only a hypothesis about it.

The use of media monitoring software products is linked to additional funding for research work. Since this study did not receive funding, it used the available technical and technological tools. In this connection, the research does not claim thematic coverage or representativeness. It only gives an analytical view of the derived empirical basis and puts forward hypotheses for future research.

All 69 units in the sample are subjected to content analysis. The indicator matrix is built on three main batteries: an intellectual; a position; a context. The first "Intellectual" targets the signatories of the public positions and includes basic socio-demographic indicators such as gender, age, institution, profession, distinctions, total number of signatures. The "Position" battery is aimed at exploring the actual position of the text. It includes genre; issue; addressee; language; discourse; function; date. The third battery, "Context", examines the sociopolitical context in which the position appears and includes: events around the date of the position; impact of the position; comments on position.

\section{Theoretical perspective and working definition of intellectuals}

What is an intellectual and, in particular, what is the vision of the Bulgarian intellectual in the mirror of their collective public positions? The first part of the question requires an analysis of the very rich theoretical heritage, where the relatively small share of Bulgarian theorizing of the Bulgarian intellectual, his role and functions in society is obvious. The literature review highlighted biographical and historical, literary and philosophical studies, tracing life and creativity, historical mission and philosophy of Bulgarian and foreign intellectuals and intellectual circles. Significantly less are the sociological conceptions of intellectuals, their public mission and realization. Here, Ivailo Znepolski's research of the intellectual of the 1990s (Znepolski, 2003) and the dynamics 
among philosophers and historians of Sofia University in 1956-1989 (Znepolski, 2016) can be distinguished.

Accordingly, what is an intellectual? Among the reviewed sociological works, developed in the twentieth century mainly in English, the following relations are most often established.

Idea - Intellectual (Coser, 1965 [1997]). It is known that intellectuals move the world ahead through ideas. They manage processes, but not necessarily at the political level, as it most often comes to mind. Above the level of politics there are at least two more level that are the natural habitation of intellectuals - the ideological and the cultural-spiritual. These two levels are fueled by ideas, by a constant flow of ideas conceived of through waking independent minds who formulate and interweave them in relevant life philosophies (Rand, 2008)

Intellectuals are a professional class, uniting people whose profession is primarily related to the production of ideas - writers, scholars, academics and others (Sowell, 2009). Hayek calls them "secondhand dealers of ideas", who have mastered communication techniques to present ideas, but are amateurs on the very nature and core of ideas. He also claims that intellectuals are "the organs that modern society has developed for the dissemination of knowledge and ideas, and they are their convictions and opinions which act as the sieve through which all new conceptions must pass before they can reach the masses" (Hayek, 1949 [2010]).

Value-Intellectual. Julien Benda, setting the foundation of classical sociology of intellectuals in the $1920 \mathrm{~s}$, defines intellectuals as devoted to universal values beyond the material world and opposes them to laymen who pursue private political and power interests, and find satisfaction in the material (Benda 1927 [2007]).

Truth - Intellectual. According to Michel Foucault, the intellectual is a person who uses his knowledge, competence and connection to the truth in the field of political struggles (Foucault, 2000). Further, Foucault introduces the ancient Greek concept of "paresia" to emphasize not only the need for freedom of speech in modern democracies but also the moral obligation to the public enunciation of truth in the name of the common good and despite the risks to the spokesperson (Foucault, 2016). He distinguishes universal and specific intellectuals according to the regimes of the truth they are able to enunciate.

Synthesis - Intellectual. Karl Mannheim focuses on the following three characteristics of intellectuals: a wide-angle view, interest in seeking integrity in the socio-political structure and mental orientation towards synthesis (Mannheim, 1956). Hayek compares the intellectual with the philosopher as they both share the same drive for a logical worldview; the attitude of perceiving new ideas not according to their objective merits, but according to the ease with which they fit into the already constructed views; the pursuit of methodical synthesis (Hayek, 1949 [2010]). 
Power - Intellectual. On the one hand, there is the question of the symbolic power and symbolic capital of the intellectual, as well as the autonomy of the intellectual. Joseph Schumpeter speaks of the power of the spoken and written word that intellectuals exercise and draws attention to the fact that this power is not combined with direct responsibility for practical affairs (Schumpeter, 1943 [1994]). On the other hand, in the relation power - intellectual stays the intellectual's relationship with the political and state power. Intellectuals rarely enter into professional politics, Schumpeter writes in 1943. Shills warns that too much involvement in the state affairs would undermine the intellectuals' true role of responsible critic (Shills, 1961). Merton goes further in his statement that when intellectuals participate in the government, they have lost their autonomy (Merton, 1945 [1958]). The structural-functionalist paradigm reserved a special role for intellectuals as 'non-material' factors of effective social action" (Parsons, 1969). According to Parsons, intellectuals are specializing in cultural concerns, they are elaborating the symbolic system of social groups and are relieved from responsibility of societal functions.

It would be interesting to check whether this is still true in Bulgaria today. It could be expected that one of the Bulgarian intellectuals's coping strategies is precisely the entry into politics. Hayek argues that the influence of intellectuals on politics and political decision making is negligible. Their power is in the process of forming public opinion and from there on the politics of tomorrow (Hayek, 1949 [2010]). According to Pierre Bourdieu, intellectuals are counter-ideologists, called to ruin ideological misconduct and manipulation (Bourdieu, 2008).

Alienation - Intellectual. Edward Shills draws attention to disjunction in the intellectuals 'role among their universal ideals and society's more mundane concerns that led to intellectuals' alienation (Shills, 1958 [1972]). Charles Mills gives another reason for the alienation of intellectuals. In his view, intellectuals know much more than what they are allowed to enunciate. This accumulates tension, a sense of powerlessness and alienation (Mills, 1945). Insofar as intellectuals are gifted people, it is normal for them to have problems in handing over their gift to society, which rather does not want to accept the gift (Campbell, 1949 [2008]). On the basis of the research of the world mythology, Campbell outlines three strategies for conveying the gift to society. The first turns the intellectuals into self-satisfied, self-contained, alienated from their community, sinking into the depths of their insult, despair, malice, anger or other emotions with low vibrations that swamp the way forward. The second turns intellectuals into merchants of their gift. They spread their gift in works at the level of mass taste and need and hope that one day when they get rich enough, they will realize their gift at its height. The third decision is taken by the true intellectuals. They become teachers who are looking for and finding the most appropriate ways 
to convey the gift to society so that it accepts it and through it to continue its development.

Intervention - Intellectual. The relation is proposed by the so-called sociology of interventions, which claims to be the successor of classical sociology of intellectuals (Eyal, 2010). Sociology of interventions place an emphasis not on the intellectual as a social type, but on the process of mobilization of knowledge and expertise in intervening in the public sphere. Seven modes of intellectuals' intervention are distinguished: the critical, universalistic intellectual; the custodian of the moral order; intellectual contentious groups and avant-gardes; intellectuals from institutions or political organizations; the expert; the specific intellectual; the collective intellectual. (Sapiro, 2009).

Based on the relations intellectual - idea, value, truth, synthesis, power, alienation, intervention - the following working definition of an intellectual could be proposed. The intellectual moves the specific energy of thought and ideas in society, which is the very basis of his symbolic power and capital. On the other hand, the same is a factor for his alienation. The intellectual develops synthesized explanations of the present and projects, visions, strategies for the future, based on their value orientation and their closeness to truth. He intervenes in the public sphere of politics and state power as a counter-power or as a supportive power. The interventions determine the public engagement and visibility of intellectuals that distinguish them from their colleagues in the relevant professional field. Posner identifies multiple genres of public intellectual engagement: selfpopularizing, own-field policy proposing, real-time commentary, prophetic commentary, jeremiad, general social criticism, specific social criticism, social reform, politically inflected literary criticism, political satire, and expert testimony (Posner, 2001).

Following the working definition, it is expected that intellectuals accumulate positive public attitudes and high trust. The key to the public attitude to them is their value orientation and their closeness to truth, which encounters, attracts, collides, or diverges from the values and understanding of the truth of the audience. The history of sociology of intellectuals shows three periods in the research of the role and functions of intellectuals in society and three different modes of attitude towards them (Kurzman, 2002). The first period encompasses the 20s of the 20th century, when the methodological foundations of discipline were set and the attitude towards intellectuals was rather negative. They are "largely demoralized" and undergoing an intense spiritual self-criticism. The 20s of the twentieth century are marked as anti-intellectual intellectuals' time (Adorno, 1964 [1973]). The midst of the century, after the Second World War, could be defined as the intellectuals' Golden Age. Many intellectuals have been directly involved in solving the problems of post-war Western European and American society. East European intellectuals took leadership in the process of social change. In 
the last decade of the last century, the sociology of intellectuals was enriched by a vast collection of theoretical conceptions and empirical studies of intellectuals, but the intellectuals themselves remained rather in a passive position. Bauman called the fate of the late century European intellectuals "the fall of the legislator" - the loss of intellectual confidence in their ability to propose a rational vision for society (Bauman, 1987). The research of the dynamics in the Bulgarian attitude to Bulgarian intellectuals would be interesting. Here, this review was made to emphasize the ambiguity in the perception of intellectuals and to direct the thought to the second question - what is the image of the Bulgarian intellectuals at the beginning of the 21 st century according to their publicly expressed collective positions. Each of these positions is a form of intervention in the political field.

\section{The Bulgarian Intellectual as a citizen}

The review of the names under the collective public positions shows first the professional affiliation of the Bulgarian intellectuals. They are academics and university lecturers; performing arts - most often literature and drama, cinema and theater, music and fine arts; teachers and others involved in education; journalists; athletes; representatives of non-governmental organizations. Almost all of them occupy medium and high positions in their professional fields, build and use their public authority and symbolic capital.

Besides being professionals, the Bulgarian intellectuals are citizens with an acute sense of civic consciousness and, given the intensity of their petition activity, they claim to have an active civic position and high public responsibility. They proclaim themselves as citizens, not as intellectuals or the like, in the last "Open Letter" of May 22, 2019 [1]. The content analysis of the all 69 positions included in the sample shows that apart from six positions, in all the rest the signatories identify themselves either by their main occupation or as citizens or as public figures. One of the six positions is in fact a satirical replica of Ivan Kulikov expressing the powerlessness of the collective action of the intellectuals [31]. (See Table 2).

Why do intellectuals prefer to name themselves as citizens? Intellectuals are publicly recognized citizens, as their collective petitions reveal, who perhaps prefer not to call themselves intellectuals out of modesty. In fact, intellectuals are not self-styled. An outside instance legitimizes their status and authority of intellectuals. Here comes the question as to which are the legitimating instances in the Bulgarian intellectual field today? Bourdieu distinguishes legitimate instances (university, academies), competing and claiming to be legitimate (critics and clubs) and illegitimate (fashion, advertising) (Bourdieu, 2012). Could it be that the media, rather than the academy, the political parties or the university, 
is the legitimating instances with the greatest weight? The results of the survey can only direct the answer.

Perhaps the signatories choose to identify themselves as citizens or members of a professional group to expand their initiative beyond the intellectual field. This approach would also solve another abovementioned problem with the working definition of intellectuals, namely alienation. It is natural and expected that intellectuals should seek greater audibility and visibility, receptivity to the audience. One of the methods to achieve greater recognition is to include the audience as an active actor in an initiative. This method has the potential to ease the audience's mistrust and tension and to neutralize the possible reaction of rejecting the point of view, the thesis, the new idea of the initiative offered by the intellectuals. In defining the intellectuals, Hayek draws attention not only to their communicativeness but also to their manipulation (Hayek, 1949 [2010]).

A possible explanation could also be sought in the desire of contemporary Bulgarian intellectuals to escape from negative associations that the "intellectuals" provoke. Are Bulgarian intellectuals running out of their roles? This is an interesting question, which is essential to the understanding of the key public processes unfolding in Bulgaria today.

The history of the sociology of intellectuals shows a variable public attitude towards intellectuals in the twentieth century. The Bulgarian intellectual at the beginning of the 21 st century inherited his ancestors from the 1990s who, if immediately after 1989 , took high political positions - for example $21-22 \%$ of the general composition of the Grand National Assembly comprised deputies from the circles of the Bulgarian intellectuals, in the late 1990s they came to "losing their political weight and the wear of their symbolic power" (Znepolski, 2014). Duhomir Minev speaks about an intellectual crisis as a result of the expropriation of the monopoly over the right to define risks to the development of society by politicians (Minev, 2011). This crisis is a consequence of three historical revolts that took place in the twentieth century. Today, at the start of the 21 st century, they act together with another crisis which is in its beginning.

This crisis pertains to the ongoing revolt of the masses (Gasset, 1930 [1994]), which still continues to lift up the layman into the elite, to raise him to the high levels of public responsibility. As for the Bulgarian intellectual field, the manifestation of this revolt is in the 1960s when, "Ideology determined the hierarchy in society, and it was automatically transferred to the university. Apparatus professors, because of their biography and attitudes, occupy all the leadership positions in the university hierarchy... They represent the institutionalized authority at the university" (Znepolski, 2016, 63). The same ascent of the "little man" in the university hierarchy is also observed by Doncho Gradev after 1989, when ideology was changed, and the new ideology redefined and established the hierarchy in a democratic society in a similar fashion. The university is the last social refuge 
of the "little man", but his penetration and dominion in the field of science and among intellectuals has deep devastating effects, since being an intellectual with authority at university the "little man" could model the thinking of every next active generation (Gradev, 2015).

The revolt of the masses and the rise of the mass-man in power is followed by a revolt of the elites (Lash, 1997) or the elites' escape of their public responsibilities, which is today in full swing. There is also a manifestation of this revolt in the intellectual field. The question, for example, is whether there is an intellectual elite in Bulgaria, what is its mission and influence on the dynamics of public life. Or perhaps the role of the intellectual elite is the seizure by the populist elite of some influential party? It seems that intellectuals are once again entangled or fairly entangled in the circles of the political.

The revolt of the elites practically stifles and melts down the middle class. New elites do not need the expertise and competence of the high middle class where the intellectual elites are positioned. This includes the contemporary war against science, artistic arts, the downgrading of evaluation criteria, the diminution of achievements, and the credibility. Intellectuals are needed to create and validate opinions, but it would be most useful if they themselves have no opinion. This is indeed a delicate situation.

Here is what Stefan Tsanev says in 2016: "It's a shame to say things that are obvious, and they (the politicians) pretend that they cannot hear anything. Even more offensive is the way they use us, the so-called intellectuals. I recently watched one footage on TV, and the saddest comparison came to my mind. A rocket had been launched into space. Once it gained momentum to get into orbit, its rocket carriers were thrown out. So, I saw myself as one of the rocket carriers of several political figures who, after speeding up, got rid of me. I'm not complaining about that. What is important is the rocket to do its job" (Veleva, 2016).

Perhaps this delicate situation is the reason why in petitions, intellectuals are more often legitimized through their profession and significantly less often through the institution they belong to. The research distinguishes between the following types of legitimating institutions: academies and universities; nongovernmental organizations with a wide range of activities; cultural institutes (theaters, libraries, etc.) and centers; media; business and business organizations. Not few are the petitions under which the signatories only place their names. In today's legitimacy crisis, institutions are expected to reduce public confidence in the position. It is possible for intellectuals to avoid them both from professional ethical considerations and from individual emotional states related to loss of position, work, clients.

Whether Ortega and Lash imagined that there would come a time when the mass-man occupying the throne of power would not only refuse to fulfill the social responsibility of his elite status but would also deprive anyone else to take 
the responsibility? After all, today the "open society" has come to a closed circle of which there seems to be no exit.

In the scientific literature, in the media, and in everyday talks, this circle of collective elite irresponsibility often gathers thoughts. It itself provoked the third revolt - the information agents' revolt, and its first result is the saturation of the public information field by numerous warring armies of information units, each claiming to be closest to the truth, to communicate and affirm the deepest truth for power, i.e. to play the role of an intellectual.

The coping strategies of intellectuals in the context of these three revolts are interesting. Thomas Sowell distinguishes the following models: vertical - the intellectual is oriented to positions with real power - for example many Bulgarian intellectuals are candidates for politicians. Horizontal - when the intellectual changes the intellectual field with another one, including outside their homeland. The activity of intellectuals in the social media - the new public space where we relieve the accumulated social tension and create consolation that dialogue and sharing and mutual assistance exist. It seems that intellectuals exchange too much information through social media. Probably the self-publishing by selfimage making in social media is the third coping strategy of intellectuals during three mutually revolting revolts - the revolt of the masses, the elites and those of the information agents? Perhaps there is a fourth, provoked by the fourth revolt the people's riot that Steve Bannon recently spoke about (Bannon, 2019).

After the revolt of the elites, the people's response is expected and logical. However, the question is whether it has started yet or it is just an idea, an expectation, an early warning of an intellectual. The answer deserves scholarly attention. The fact that in their public positions the Bulgarian intellectuals identify themselves as citizens and seek identification with citizens in order to establish a norm of attitude or behavior towards the political process is enough to direct the answer. It is enough to suggest that the fourth strategy to address Bulgarian intellectuals today is building and maintaining an active relationship with the citizens. Winning the audience is a way to increase the social capital and symbolic power of intellectuals. Increases their self-confidence. It can serve as an instrument for exercising effective civic pressure on political processes. But it can also be used to win political orders. The new media provide a great opportunity to develop a relationship with citizens and to form audiences. Do the intellectuals use this potential and how could it become the research topic of a next study?

\section{Three generations of intellectuals}

A generational cross-section could be made in the prism of public positions of intellectuals. Even in the perspective of the first glance on the total list of signed intellectuals (between 1400 and 1600 unique names), three generations 
could be distinguished. The generation of the "Children of Transition", born in the 1970s-1980s, today's 30-40-year-old, who are the active human power of any society, has the poorest presence. On the contrary, the generation of the "Parents of the Transition", today's 50-60-year-old, stands out with the highest activity. We also see the names of intellectuals and even an intellectual elite from before 1989, here called "Grandparents of the Transition". The outlined proportion of generational activity - the "Parents" as the most active, followed by "The Grandparents" and the "The Children" as the least active, has its sociodemographic, cultural and civilizational explanations, detailed in a previous study (Mihailova, 2018).

The "Children of Transition" in the period 2005-2019 (in which the petition here are dated) are primarily involved in resolving other life tasks that govern their family and professional status - for example the family - professional carrier dilemma (Kineva, 2015), especially for women or the position in the university structure - "Children" are mostly lecturers without habilitation working for their habilitation or generally speaking - for taking a secure position in the university structure, and their efforts are expectedly aimed at solving this task. Here, attention should also be paid to the macro-indicator of intergenerational social and economic mobility, which reports a delay in mobility in the "Children's generation" compared to that of the "Parents" (Narayan, 2018).

The activity of the "Parents" according to Ivaylo Znepolski (he himself is from the generation of the "Parents") is a compensation of the intellectuals' deprivation of the possibility to directly address the people and state institutions before 1989, which is manifested in the petition activity of the generation in 90 s of the twentieth century and later on (Znepolski, 2014). There is another argument - political engineers or political parties encompass and activate intellectuals after 1989, the generation of the "Parents", which in the 1990s was the new active generation, to use them in favor of their ideas for development of the young Bulgarian democracy and its transformation into a decoration of power. This continues to this day with newcomers from the next generation. Here is what Kiril Velev writes: "In the years of transformation, the Bulgarian intellectual elite was crucified among the political poles, was constantly tempted by the flirt with power, and ultimately usable without being able to fulfill its mission." (Velev, 2009).

The "Grandparents of the Transition" are the generation that survived the revolt of the masses and the rise of the mass-man in power. They also have experience with the second historical revolt of the late twentieth century - the revolt of elite, and with the subsequent third revolt of Information Agents from the beginning of the 21 st century as well. In the context of the third revolt, one of the reasons for the poor activity of the "Grandparents generation" is the label "Former State Security Agent", which at times runs across the networks of intellectuals. In 2011, it became known that 183 of the intellectuals used to be employees of 
State Security before 1989. In 2018 it became known that another 17 used to be such, though upon closer scrutiny it turned out that this pertains to the same people. If this is the big problem with the activity and public performance of the intellectuals' network, we can expect that it will be drastically reduced in the course of time in the next generations. There remains, however, a sociopsychological attitude that defines the patterns of generational reconciliation and activity among the intellectuals' networks transmitted in an artistic form by Umberto Eco: "At university, things go back to things in the normal world: not the children hate their fathers, fathers hate their children." (Eco, 2015) Perhaps this is also the reason why the "Children" are less likely to be active in the public collective positions of Bulgarian intellectuals at the expense of the representatives of the "Parent" generation.

\section{Intellectuals in the field of ideas}

What ideas present and defend Bulgarian intellectuals through their collective positions?

The research findings expose that the direct addressee of all positions, with the exception of the last "Open Letter to Bulgarian Citizens on the occasion of the celebration of the Bulgarian culture and the elections for the European Parliament" from 22.05.2019 [1], is in the political field - parties and institutions of local and state government. The intellectuals most actively intervene in the political field and political problems - 44 out of 69 positions directly address the course of the political process. The rest pose problems in the sphere of culture, church, education (see Table 2). This shows a clear connection between intellectuals and politicians, which could pose a series of questions. In the context of this study, it all boiled down to the issue of the functions of publicly expressed collective positions - whether they are an instrument of politics, follow the political or are a form of civil pressure on politics as they bring ideas for the development of society that politics should follow. The second option leads to the confirmation of the thesis of the intellectual as a carrier of innovative ideas for the development of society while the first one leads to an imaginary figure called an intellectual who is activated and acts in the course of implementing some political goal.

It seems that political parties as agents in the political process as well as other actors in the political field are leading intellectuals, as the collective public positions of intellectuals do not precede but rather follow a political action, and argue or refute expressed attitude or intent. Out of a total of 51 positions (44 with direct political themes and 7 with cultural and political themes), only 20 are exceptions insofar as they express common values or address a vision of the future, for example: "Declaration on Cultural Reforms" (2018) [7], "Manifest for republic" (2016) [27]. Such a conclusion can also be made with regard to 
the public positions of intellectuals raising issues of church, religious, cultural or educational issues. The activity of intellectuals was triggered by a specific occasion on the part of the Bulgarian Orthodox Church in five out of the six public positions under consideration. Two out of the five positions on cultural issues are not preceded by a specific political action, rather they are intended to make an early warning or civil pressure in a process that has already begun. These are "Letter to the Mayor of Sofia for the Preservation of the Svetlin Rusev Collection" from 2018 [8], "Letter to the Minister of Culture of Banov for Debugging Books" in 2018 [15] before discussing the Copyright and Related Rights Act in the Committee on Culture and the Media in the National Assembly. The problems of Bulgarian education are a frequent focus of public debate. The sample includes only three public positions of intellectuals in this field. One is a reaction to a political decision - a Statement against the elimination of Emilian Stanev from the curriculum (2018) [14], the other expresses a position in principle addressing the problems of higher education - "Open letter to President Plevneliev about the critical state of higher education" (2015) [33] and the third is the Petition against the return of the NGDEC in "Moderno predgradie" [38]. (See Table 2).

The results rather point to Hayek's definition of intellectuals as second-hand dealers of ideas, not as bearers and speakers of their own new ideas. Who do they buy ideas from? Since the majority of their public positions follow political action, then the probable vendors of ideas are in the political and the state power domain. Therefore, the bearers of ideas are politicians and corporate managers, and intellectuals only use their high degree of social intelligence to resell the ideas to the audience in the appropriate commercial form. Obviously, they have chosen to be merchants, which, according to Campbell, is the second strategy to deliver the gift (given that ideas and rhetorical mastery are gifts) to society (Campbell, 1949 [2008]).

\section{The Public Intellectual}

Political parties are raising their intellectuals and experts. These are the so-called public speakers, public intellectuals. So, it is possible to expect that at least two networks of public intellectuals - one around the left political space and another around the right, are operating now. They are needed to express and validate the positions of the parties. They are also needed in the process of formation of public opinion and positive public attitudes. Mihail Mirchev talks about circles of political talk as a model for successful political communication. In this model intellectuals - experts are placed in a "second periphery", forming "expert circle of" the independents (Mirchev, 2015)

The need for public intellectuals normally grows during an election campaign. Apart from being public speakers, they are often organized in initiative committees to support one or another candidate. Initiative committees nominate independent 
candidates by law, but there is no legal breach in case a party candidate is supported by a petition of intellectuals who form an initiative committee. For example, intellectuals stood behind President Rumen Radev in 2016 [25,26], behind the nomination of Velichko Minekov as a presidential candidate in 2016 [24], behind Vezhdi Rashidov after his first term in office as Minister of Culture and against Vezhdi Rashidov in 2014 [42], in support of the second term of President Georgi Parvanov in 2006 [67] and others.

Public intellectuals as intellectuals who publicly express their views about major problems before the general public (Posner, 2001) are expected to form the core of the intellectual elite as the elite is a group standing at the top of the societal pyramid whose members, as a result of their extraordinary hereditary or acquired qualities, achieve success and gain power and authority. These are the intellectuals who sign public collective positions, as well as intellectuals whom the parties or businesses send to the media to assert their positions. They are also intellectuals whose analysis is sought, or even ordered by the media outlets themselves as civil society agents. These are the so-called media intellectuals (Bourdieu, 2012). Publicity, visibility is a key feature of the elite - the elites are governing, and governance in democratic regimes should be public.

According to Max Weber, the higher social status means a greater concentration of three resources - funding, power and authority. Therefore, the elite whether political, economic, cultural, intellectual - is distinguished by them.

Do the Bulgarian public intellectuals have power? Yes, they have conditioned power (Galbraith, 1985) or even symbolic power. Are they able to realize this power in the public interest? At best just half of it. Intellectuals, and even more, the intellectual elite is called upon to work at the levels above the political-ideological and cultural-spiritual, and to elaborate the ideological and methodological fundaments of the strategic vision for the development of society. This half is still far from the Bulgarian intellectual elite perhaps because there are some elite intellectuals but there is no intellectual community, no intellectual elite. Public intellectuals in Bulgaria are more often engaged not in the creation of visions but in the consolidation of existing political or party positions. This is what they actually do through open letters and petitions that appear on the occasion of a political decision or support or refute this decision. Referring to the 69 public positions of intellectuals in the period 2005-2019 it could be concluded that intellectuals follow the politicians rather than lead them. Moreover, most of their demands have not been taken into account, they have not changed the political decision (see Table 2).

The Mayor of Sofia does not stop the Sofia Pride (Gay Pride) in 2015 as a group of public intellectuals has insisted [36]. And the ratification of the so-called Istanbul Convention did not happen despite the open letter of 286 university lecturers of 2018 [11]. The independence of Kosovo was recognized by the Bulgarian National Assembly in 2008 [61], despite a petition of intellectuals against such recognition, 
the Bulgarian government did not take part in choosing a new name for the Former Yougoslav Republic of Macedonia in 2018 [10] as intellectuals recommended. The old name of the Shipka mountain peak was not returned by President Parvanov [65] or by President Plevneliev [28]. The Bulgarian Orthodox Church did not manifest itself as the Mother Church of the Macedonian Archbishopric in 2017 [19] and did not question the Macedonian Orthodox Church's autocephalousness before Russian Patriarch Cyril in 2018 [12]. Parliament did not recognize the Armenian genocide just a "mass extermination"1 ${ }^{1}$ and the persecution of Thracian refugees as intellectuals insisted in 2015 [34]. Again in 2015, intellectuals unsuccessfully demanded that the government should take a stand on the refugee problem [32]. They failed to push through the resignation of Tsetska Tsacheva as Minister of Justice in 2017 [22], or that of Sergey Stanishev as leader of the Bulgarian Socialist Party (BSP) and the Party of European Socialists (PES) in 2013 [49]. In 2010 they demanded the resignation of Sergei Ignatov, Minister of Education and Science [58], but he submitted it in 2013 at the request of Prime Minister Boyko Borisov. In 2013, they sent an open letter to Prime Minister Plamen Oresharski against the appointment of Ivan Komitski as director of the Archives [51]. Komitski was replaced in 2015. Intellectuals were against the dismissal of Prof. Alexander Chirkov as director of the hospital "St. Catherine" in 2005 [69], which did not have a tangible effect.

The position against Delyan Peevski's appointment as head of the State Agency for National Security in 2013 [48] succeeded, though it remains unclear whether this was the result of the insistence on the part of the intellectuals or part of a larger-scale protest action. The demand for the resignation of Slavi Binev as chairman of the Parliamentary Committee on Culture and Media in 2014 [37] suceeded but it was again part of a larger-scale protest organization. The solitary request for the resignation of Vezhdi Rashidov as chairman of the same commission in 2017 failed to bring any effect [21].

What is the financial well-being of the Bulgarian intellectuals, of the Bulgarian intellectual elite? Does it meet high-middle class status?

Finally, there is the issue of authority. What is the authority of a Bulgarian intellectual? The topic deserves special research attention. There has been talk about a crisis of legitimacy in Bulgarian society. The crisis undermines the authority not only of the ruling politicians, who have the legitimate right to exercise violence, but of everyone else from the macro to the micro level of the societal system, including intellectuals. There has been negative talk against them, their positions have been inveighed. However, the intellectuals are still in force. Obviously, they have a kind of immunity that preserves their authority.

\footnotetext{
1 Bulgarian National Assembly. Declaration for recognition of mass extermination of Armenian people in the Ottoman empire. 24.04.2015.
} 
Most likely, this immunity is connected to the archetype of knowledge that the general public worships and presumably attributes to intellectuals.

\section{The Intellectual in the War of Values}

Znepolski argues that intellectuals in the 1990s are waging war on petitions (Znepolski, 2014). Chavdar Hristov introduces the concept of a war of ideas, which denotes the very essence of the new era (Christov, 2014). The content analysis of the public collective positions of intellectuals leads to the conclusion that the war on petitions of 1990s was coming to an end. If petitions in the 1990s were reduced to slogans, then the petitions from the early $21^{\text {st }}$ century offer either extensive or concise texts that explain the issue at stake. If at the height of the Petition War they was no intellectual talk, but rather a radical political discourse that persistently called for and warned of the responsibility you take on if you fail to follow it, it could be argued that the new century petitions are far more moderate in style and rhetoric. The edification discourse is replaced by explanatory discourse. What is also missing is the dystopic discourse that opens up room for hypothesis that fear as an emotion is not so much exploited by the intellectuals in their public collective positions, as it used to be the case. If in the 1990s "the intellectuals inflating the pipe, have been mobilized to defend the party cause", this situation has been largely preserved. Table 2 provides enough arguments in favour of the thesis. However, it should be noted that the leftist intellectuals never respond to their colleagues from the right end of the political spectrum and vice versa, given that there are no two contradicting positions on a single problem. As the results show, each of the two networks has its own sphere of action and uses public positions to raise a certain set of issues. It seems that there is no dialogue between the two groups.

These results give rise to the question of the type of war in which Bulgarian intellectuals are involved at the beginning of the new millennium. It is the war of petitions that makes them a political instrument, undermining the autonomy of the intellectual field or is it the war of ideas where they present visions, causes, missions, doctrines and ideologies that drive the political process? They seem to be involved in both types, as the war of ideas is manifested through publicly expressed collective petitions. However, they are not Generals, just Officers positioned along the two sides of the global ideological-value front today.

Based on an analysis of public positions, it is possible to talk about the existence of two major networks of intellectuals (see Table 2). There have emerged two value-based cores, formed mainly along the key geopolitical opposition lines in Europe and the world today, and they can be clearly distinguished. The results show that certain names have a frequency of repetition, though not in all but only in a certain number of positions that follow their political line. These include, for example, the petition in support of the student protests in 2013 [47], the open 
letter for specialized monitoring of the "Deconstruction" radio broadcast in 2014 [40], the letter to the National Assembly on the immediate ratification of the Istanbul Convention of 2018 [11] or the "Open Letter to Bulgarian Citizens" before the European Parliament elections [1]. Another group of same names are also found under the positions of intellectuals in the protection of the Bulgarian Orthodox Church from 2012 [54] or under the petition for recognition of the Armenian genocide and the persecution of the Thracian refugees in 2015 [34] as well as the initiative committee set up in 2015 in support of the candidacy of Rumen Radev for president of Bulgaria in 2018 [26].

The value foundations as well as the language of the positions of the two groups also differ. Within these two opposing networks of intellectuals, separate nuclei that express and defend some private interests are formed, for example: the petition against the dismissal of Prof. Alexander Chirkov of the intellectuals from the town of Lom in 2005 [69], the letter to the chairman of the Plovdiv Municipal Council against the demolition the building of the emblematic "Cosmos" cinema, signed by Plovdiv intellectuals in 2011 [57] or their petition for the conservation of the frescoes of the "St. Marina" church in 2012 [55], also the open letter of lecturers from the Department of Sociology at Sofia University "St. Kliment Ohridski" for compliance with the professional standards in sociological surveys in 2014 [41], the letter to the Mayor of Burgas demanding that the Burgas Airport be named "Hristo Fotev" after the name of the famous poet born in Burgas in 2017 [20], etc., or formed on a professional basis - such as a "Statement by Bulgarian Writers to Ambassador of Ukraine in the Republic of Bulgaria" from 2019 [2] or "Letter to Tsetska Tsacheva, Minister of Justice" from 2017, signed by lawyers "with professional knowledge, long experience and definite opinion on the necessity of reforming Bulgarian justice" [22]. More specifically, these separate nuclei are thought to be social circles in each of the two networks, formed on the basis of similarities of political and value positions among the participants.

\section{Conclusion}

What is the image of the Bulgarian intellectuals in the mirror of their public collective positions from the dawn of the new millennium? The answer based on the key definitive markers for an intellectual and the empirical results suggest the following.

The Bulgarian intellectual does not lose his authority despite the crisis of legitimacy in Bulgarian society. He continues to concentrate symbolic power and capital through which he enters the flow of energy driven by thought and ideas beyond the intellectual field. Its function is rather to transfer and disseminate the ideas from the political field into other public fields. He does so by using his high social intelligence. He is more of a public mediator, a mediator of political ideas and ideologies, which somewhat contradicts his authentic role of generator of 
ideas and conceptions and his role in public expectations. Here is the key reason for a certain distancing of the intellectual, even the public intellectual, from his audience, which causes his alienation.

As the results of the content analysis of 69 public positions of intellectuals in the period 2005-2019 show, the Bulgarian intellectual responds to political events but does not offer synthesized explanations of the present, projects, visions, strategies for the future. It is possible that this may be due to the genre-related limitations of the analyzed public positions. However, this assumption could possibly be tested in a future content analysis of public and media statements of intellectuals or other forms of their activity.

This study raises a number of questions on which the assumptions for further research could be based. Yet answers cannot be given because of the limitations of its research topic. In order to construct a fuller image of the Bulgarian intellectual at the beginning of the $21^{\text {st }}$ century it is necessary to explore other activities of the intellectuals - their media statements, participation in public debate, the forms of their participation in the political field, for example. Network analysis would provide significant results on the structure and operation of intellectual networks, since the answer to the question of who is the Bulgarian intellectual also suggests research on the networks in which the intellectual participates. In a genetic-structuralist perspective, the genesis of the Bulgarian intellectual and the intellectual field in our country can be traced. In a structural and functional perspective, the dynamics of the status, position and functions of the Bulgarian intellectual today in the system of Bulgarian society can be revealed.

Table 1. Research Sample: 69 public collective positions of Bulgarian intellectuals (2005-2019)

\begin{tabular}{|c|c|l|}
\hline № & Date & \multicolumn{1}{c|}{ Title and Content } \\
\hline 1 & 22.05 .2019 & $\begin{array}{l}\text { Open Letter on the celebration of the Bulgarian culture and the elections } \\
\text { for the EP }\end{array}$ \\
\hline 2 & 30.05 .2019 & Statement of Bulgarian Writers for recall of Ambassador of Ukraine \\
\hline 3 & 11.01 .2019 & Letter in support of Minister of Interior Krassimir Karakachanov \\
\hline 4 & 22.01 .2019 & Declaration in support of Angel Dzambazki's candidacy for MEP \\
\hline 5 & 4.02 .2019 & Address claiming for destruction of the monument of Alyosha in Plovdiv \\
\hline 6 & 26.11 .2018 & Statement of the "Unity" Association for national unity and tolerancy \\
\hline 7 & 24.05 .2018 & Declaration of the civil movement "For Reforms in Culture" \\
\hline 8 & 30.10 .2018 & Open letter for conservation of Svetlin Rusev's collection \\
\hline 9 & 18.09 .2018 & Proclamation for the unity of Bulgarian nation \\
\hline 10 & 26.06 .2018 & Declaration on the new name of the Former Yugoslav Republic of Mecedonia \\
\hline 11 & 29.01 .2018 & Petition insisting on the immediate ratification of the Istanbul Convention \\
\hline
\end{tabular}




\begin{tabular}{|c|c|c|}
\hline 12 & 8.03.2018 & $\begin{array}{l}\text { Open letter on the visit of Patriarch Kirill and the attitude of the Russian } \\
\text { Orthodox Church and the Bulgarian Orthodox Church to the Orthodox } \\
\text { Church in the Republic of Macedonia }\end{array}$ \\
\hline 13 & 30.08 .2018 & Open letter against the monument of an emblematic communist functionary \\
\hline 14 & 29.05 .2018 & Statement against elimination of Emilian Stanev from the curriculum \\
\hline 15 & 21.02 .2018 & Petition of writers for deductions from books borrowed in libraries \\
\hline 16 & 11.09 .2017 & Claim for the use of the "Blue House" as club of cultural workers in Haskovo \\
\hline 17 & 1.03 .2017 & Petition, insisting on the retrieval of the book market on Slaveikov square \\
\hline 18 & 30.09 .2017 & $\begin{array}{l}\text { Open letter against the election of Anton Todorov as Chairman of the } \\
\text { Commission for Files }\end{array}$ \\
\hline 19 & 21.11.2017 & $\begin{array}{l}\text { Open letter claiming that the Bulgarian Orthodox Church should accept } \\
\text { the Macedonian Orthodox Church }\end{array}$ \\
\hline 20 & 29.03 .2017 & Open letter proposing Burgas Airport to be named "Hristo Fotev" \\
\hline 21 & 15.05 .2017 & $\begin{array}{l}\text { Petition against Vezhdi Rashidov, chair of the parliamentary commission } \\
\text { of culture and media }\end{array}$ \\
\hline 22 & 14.06 .2017 & $\begin{array}{l}\text { Open letter claiming for the resignation of Tsetska Tsacheva as minister } \\
\text { of justice }\end{array}$ \\
\hline 23 & 14.12.2017 & $\begin{array}{l}\text { Open letter against awarding of the academic title "Doctor Honoris Causa" } \\
\text { to politicians }\end{array}$ \\
\hline 24 & 28.07 .2016 & Address in support of the candidacy of Velitchko Minev for president \\
\hline 25 & 9.09 .2016 & $\begin{array}{l}\text { Petition of Plovdiv intellectuals supporting the candidacy of Roumen Radev } \\
\text { for president }\end{array}$ \\
\hline 26 & 20.09.2016 & $\begin{array}{l}\text { Petition supporting the candidacy of Roumen Radev and Iliana Yotova } \\
\text { for president and vice president }\end{array}$ \\
\hline 27 & 3.03 .2016 & Manifest for the Republic \\
\hline 28 & 26.09 .2016 & Open letter for the name changes of Shipka peak \\
\hline 29 & 6.07.2016 & $\begin{array}{l}\text { Open letter supporting the candidacy of Irina Bokova for the Secretary } \\
\text { General of UN }\end{array}$ \\
\hline 30 & 5.05 .2015 & Open letter of left intellectuals on the occasion of the war in Ukraine \\
\hline 31 & 27.03 .2015 & Ivan Kulekov's satirical petition \\
\hline 32 & 17.05 .2015 & Statement of the migrant crisis \\
\hline 33 & 1.10 .2015 & Open letter on the critical state of higher education \\
\hline 34 & 20.09.2015 & $\begin{array}{l}\text { Petition for recognition of Armenian genocide and the persecution } \\
\text { of the Thracian refugees }\end{array}$ \\
\hline 35 & 9.03. 2015 & $\begin{array}{l}\text { Open letter - an invitation for discussion on the contributions of Tsar Simeon } \\
\text { II for the development of contemporary Bulgaria }\end{array}$ \\
\hline 36 & 24.06 .2015 & Open letter claiming the mayor of Sofia not to allow Sofia Pride \\
\hline 37 & 1.12 .2014 & $\begin{array}{l}\text { Declaration against Slavi Binev as a chairman of the Commission of Media } \\
\text { and Culture at the National Assembly }\end{array}$ \\
\hline 38 & 14.02 .2014 & Petition against the return of NGDEC in "Moderno predgradie" \\
\hline 39 & 5.02 .2014 & Petition for a national referendum on issues related to elections and voting \\
\hline
\end{tabular}




\begin{tabular}{|c|c|c|}
\hline 40 & 31.01 .2014 & Open letter claiming for monitoring on "Deconstructsia" radio broadcast \\
\hline 41 & 4.06 .2014 & Open letter on professional standards in sociological research \\
\hline 42 & 12.11 .2014 & Petition for support of Vezhdi Rashidov as minister of culture \\
\hline 43 & 2013 & $\begin{array}{l}\text { Address, claiming for reasonable support from the Government } \\
\text { to the EU integration of Republic of Macedonia }\end{array}$ \\
\hline 44 & 7.12. 2013 & $\begin{array}{l}\text { Open letter claiming the Parliament to recognize the genocide against } \\
\text { Bulgarians during the Ottoman rule }\end{array}$ \\
\hline 45 & 22.11 .2013 & Open letter condemning the excessive use of force against peaceful protesters \\
\hline 46 & 3.08 .2013 & $\begin{array}{l}\text { Open letter asking the Patriarch for a common prayer for the spiritual } \\
\text { unification and moral transformation of the Bulgarian people }\end{array}$ \\
\hline 47 & 25.10 .2013 & Position in support of the students' protest \\
\hline 48 & 1.06 .2013 & Open letter against the appointment of Delyan Peevski as chairman of SANS \\
\hline 49 & 12.11 .2013 & $\begin{array}{l}\text { Open letter claiming for resignation of Sergey Stanishev, chair of BSP } \\
\text { and PES }\end{array}$ \\
\hline 50 & 15.07 .2013 & Open letter to the starving Edvin Sugarev and Nekolay Genov \\
\hline 51 & 2.09 .2013 & $\begin{array}{l}\text { Open letter against the appointment of Ivan Komitski as chair of Archives } \\
\text { State Agency }\end{array}$ \\
\hline 52 & 1.07 .2013 & $\begin{array}{l}\text { Open letter urging president Plevneliev to warn the Euro-Atlantic community } \\
\text { about the black prospects ahead of Bulgaria today }\end{array}$ \\
\hline 53 & 13.09.2012 & $\begin{array}{l}\text { Petition urging the Sofia Regional Court to reconsider its position on parking } \\
\text { regulation }\end{array}$ \\
\hline 54 & 1.02 .2012 & Proclamation in support of the unity of the Bulgarian Orthodox Church \\
\hline 55 & 19.02.2012 & Open letter claiming for conservation of St. Marina Church paintings \\
\hline 56 & 22.06 .2012 & $\begin{array}{l}\text { Open letter against awarding the archon title to Slavi Binev and Petar } \\
\text { Mandjukov }\end{array}$ \\
\hline 57 & 16.02 .2011 & Open letter against the destruction of the building of "Kosmos" cinema \\
\hline 58 & 9.11 .2010 & $\begin{array}{l}\text { Open letter claiming for the resignation of Sergey Ignatov, minister } \\
\text { of education and science }\end{array}$ \\
\hline 59 & 4.03 .2009 & Petition for elections 2 in 1 (Local and European) \\
\hline 60 & 2.02.2009 & $\begin{array}{l}\text { Open letter against the interference of the state institutions in the Church } \\
\text { affairs }\end{array}$ \\
\hline 61 & 19.03.2008 & $\begin{array}{l}\text { Open letter against the recognition of of Kosovo independence. } \\
\text { "Crazy lead the blind" }\end{array}$ \\
\hline 62 & 8.09 .2008 & Petition supporting Russia against Georgia \\
\hline 63 & 2008 & "800 farewell words to Simeon" \\
\hline 64 & 17.05.2008 & Open letter of intellectuals to the MP from the Union of Democratic Forces \\
\hline 65 & 26.06 .2007 & Open letter for the return of the old name of Shipka peak \\
\hline 66 & 24.04 .2007 & $\begin{array}{l}\text { Open letter for the state losses from the concessions of the gold mines } \\
\text { in Chelopech, Popintsi }\end{array}$ \\
\hline 67 & 15.08 .2006 & Petition supporting the second term in office of the president Parvanov \\
\hline 68 & 14.12 .2006 & Open letter against the TV show "The Great Bulgarians" \\
\hline 69 & 11.11 .2005 & Petition against the dismissal of prof. Alexander Chirkov \\
\hline
\end{tabular}




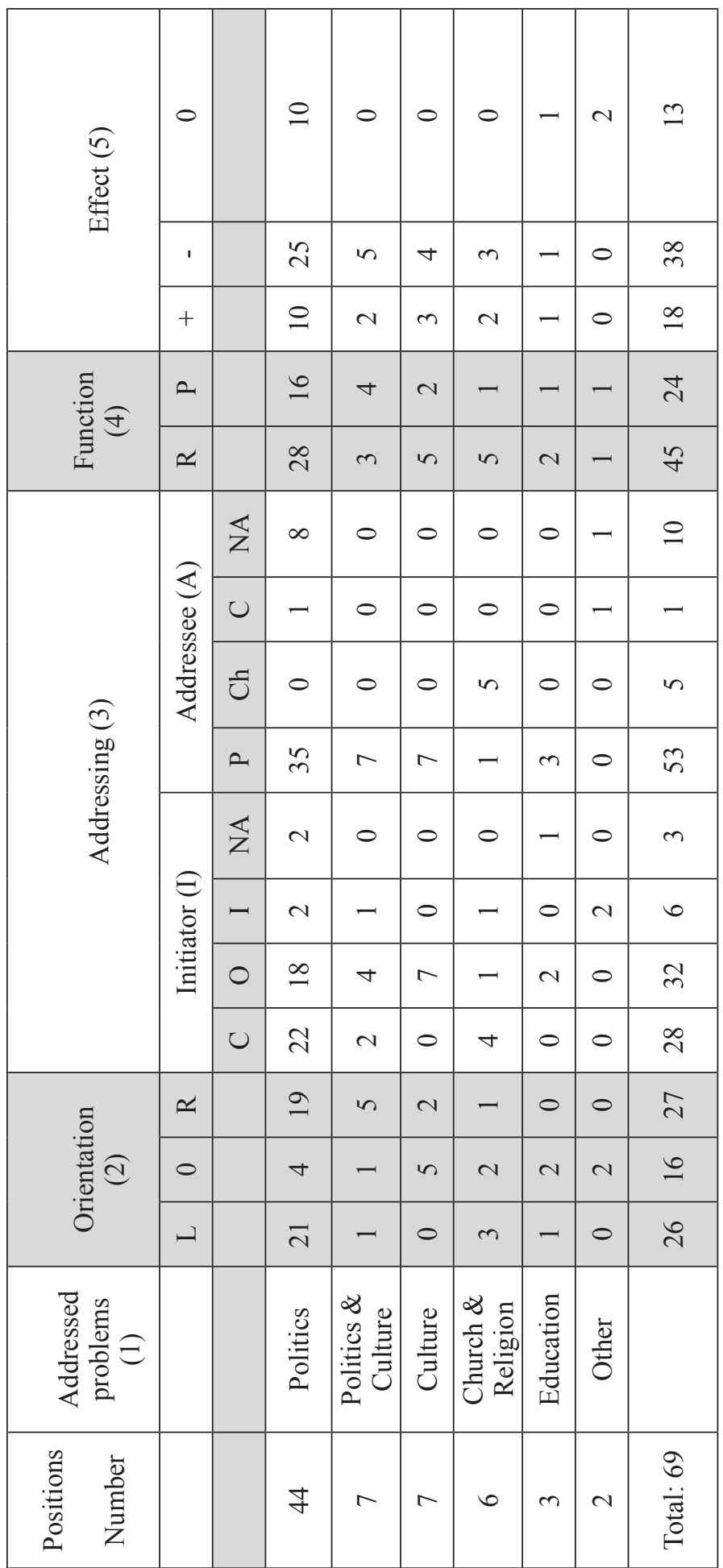




\section{Bibliography:}

Банън, С., (2019), Не вярвам в неолибералния модел. Достьпно на: http://www. glasove.com/categories/skandalyt/news/stiv-banyn-ne-vyarvam-v-neoliberalniyamodel-partiyata-na-davos-e-omagosana-ot-zlatniya-telec-no-nie-shte-ya-pobedim (Последно посетен 1 юли 2019).

(Bannon, S. Ne viarvam v neoliberalnia model. Accessible at: http://www. glasove.com/categories/skandalyt/news/stiv-banyn-ne-vyarvam-v-neoliberalniyamodel-partiyata-na-davos-e-omagosana-ot-zlatniya-telec-no-nie-shte-ya-pobedim (accessed on 1 July 2019)

Бурдийо, П., (2008), Ответен огън. София: УИ "Св. Климент Охридски", с. 11. (Bourdieu, P. 2008, Otveten Ogan, Sofia: UI: "Sv.Kliment Ohridski", s. 11.) Бурдийо, П., (2012), Полета на духа. София: Изток-Запад.

(Bourdieu, P. 2012, Poleta na duha, Sofia: Iztok-Zapad)

Велев, К., (2009) Интелектуалният елит на трансформацията. В: Нещо като преход, нещо като реформа, нещо като нищо на света. Достьпно на: http:// www.kirilvelev.com/part_05.htm\#part5.1. (посетено на 1 юли 2019).

(Velev, K., 2009, Intelectualniat elit na transformatsiata. V: Neshto kato prehod, neshto kato reforma, neshto kato nishto na sveta. Accessible at: http://www. kirilvelev.com/part_05.htm\#part5.1, (accessed 1 July 2019).)

Велева, В., (2016), След 89-та видях мечтата си омърсена! Интервю със Стефан Цанев. Достьпно на: http://epicenter.bg/article/Stefan/107263/11/0. (последно посещение на 1 юли 2019).

(Veleva, V., Sled 89-ta vidiah mechtata si omrsena! Interviu sas Stevan Thanev. Accessible at http://epicenter.bg/article/Stefan/107263/11/0. Accessed on 1 July 2019) Градев, Д., (2015), Властта на малкия човек. София: Наука и изкуство.

(Gradev, D, 2015, Vlastta na malkia chovek, Nauka I izkustvo, Sofia)

Еко, У., (2015), Нулев брой. Бард, София.

(Eco, U., 2015, Nulev broi, Bard, Sofia.)

Знеполски, И., (2016), Как се променяха нещата. София: Сиела.

(Znepolski, I., Kak se promeniaha neshtata, Ciela, Sofia.)

Знеполски, И., (2014), Интелектуалците и войната на петициите през 90-те. B: Inspiro бp., № 2 (26) /2014.

(Znepolski, I., 2014, Intelektualtsite I voinata na petitsiite prez 90-te. V: Inspiro, br. № 2 (26) / 2014) Accessible at: https://inspiro-bg.com/intelektualtsite-ivoynata-na-petitsiite-prez-90-te/ (accessed 1 July 2019)

Знеполски, И., (2003), Вебер и Бурдийо: подходи към интелектуалците, Дом на науките за човека и обществото, София.

(Znepolski, I. 2003, Veber I Burdio: podhodi kam intelectualtsite. Sofia: Dom na naukite za choveka I obshtestvoto)

Кинева, Т., (2015), Съвременната българка и колизията "семейство-работа", В: Научни трудове на УНСС, том 2-3/2015, част втора, с. 213-248. 
(Kineva, T. Savremenata balgarka v koliziata "semeistvo-rabota". V: Nauchni trudove na UNSS, tom 2-3/2015, chast vtora, s. 213-248.)

Лаш, К., (1997), Бунтът на елитите и предателството към демокрацията. Обсидиан, София.

(Lash, K. 1997, Buntat na elitite I predatejstvoto kam democratsiata. Obsidian, Sofia.) Минев, Д., (2011), Социология, власт и общества. Троян: Аля.

(Minev, D. 2011, Sociologia, Valst, Obshtestva, Alia, Troyan.)

Мирчев, М., (2015), Кръгове на политическо говорене. В: "Проблеми на обществената комуникация". Сборник с доклади от кръгла маса "Проблеми на обществената комуникация", София: За буквите - О писменехъ, с. 26-42. (Mirchev, M., 2015, Kragove na politichesko govorene. V: Problemi na obshtestvenata komunikatsia. Za bukvite - O pismeneh, s. 26-42, Sofia.)

Михайлова, К., (2018), Интелектуалните елити в три исторически бунта. В: Иванов, Д. (съст.) Мобилност на елитите на прехода (1989-2017), Бюлетин 12 на ИИРЛИС. София: "За буквите - О писменехь", 2018, с. 236-256.

(Mihailova, K. 2018, Intelectualnite eliti v tri istoricheski bunta. V: Ivanov, D. (sast.) Mobilnost na elitite na prehoda (1989-2017), Biuletin 12 na IIRLIS. Sofia: Za bukvite - O posmenah, 2018, s. 236-256)

Начева, Г., 2013, Интелектуалецът и социалистическата култура. В: Годишник на БСУ, с. 152-159.

(Nacheva, G. Intelektualetsat I socialisticheskata kultura. V: Godishnik na BSU, s. 152-159)

Ранд, А., (2008), Новият интелектуалец. МАК, София, с. 13.

(Rand, A. Noviat intelektualets, MAK, Sofia, s. 13)

Фуко, М., (2016), Управляването на себе си и на другите. София: Критика и хуманизъм.

(Focault, M. Upravliavaneto na sebe si i na drugite. Sofia. Kritika I humanizam) Христов, Ч., (2014), Войната на идеите. София, УИ "Св. Климент Охридски". (Hristov, Ch. 2014, Voinata na ideate. UI "Sv. Kliment Ohridski", Sofia.)

Чомски, Н., (2005), Необходими илюзии. София: Бард.

(Chomski, N. 2015. Neobhodimite iluzii. Bard, Sofia.)

Adorno T., (1964 [2007]). The Jargon of Authenticity. Routledge.

Bauman, Z., (1987), Legislators and Interpreters: On Modernity, Post Modernity and Intellectuals. Cambridge, Polity Press, UK.

Benda, J. 1927 [2007]. The Treason of the Intellectuals. Routledge, New York. Bourdieu, P., (1996), The Rules of Art. Genesis and Structure of the Literary Field. Polity Press.

Campbell, J., (1949 [2008]), The Hero with a Thousand faces. New World Library; Third edition. 2008)

Coser, L., (1965 [1997]). Man of Ideas. A Sociologist View. Free Press, New York. 
Eyal, G. and L. Buchholz, (2010), From the Sociology of Intellectuals to the Sociology of Interventions. In: Annu. Rev. Sociol. 2010.36:117-37.

Foucault, M., (2000), Truth and Power. In Essential Writings of Michel Foucault, Vol. 3: Power, ed. P. Rabinow, JD Faubion, p. 111-133. New Press, New York. Galbraith, J.K., (1985), The Anatomy of Power. Houghton Mifflin Company; Reprint edition.

Gasset, J.O., (1930 [1994]), Revolt of the Masses. W. W. Norton \& Company; Revised ed. Edition.

Hayek, F., (1949 [2010]) Intellectuals and Socialism. Kessinger Publishing, LLC. Kurzman, Ch. and L. Owens, (2002), The Sociology Of Intellectuals. In: Annual Review of Sociology. 28:63-90.

Lévy, Bernard-Henri, et al. (2019), "Fight for Europe - or the wreckers will destroy it", accessible at: https://www.theguardian.com/commentisfree/2019/ jan/25/fight-europe-wreckers-patriots-nationalist (accessed 1 July 2019).

Mannheim, K., (1956), The Problem of the Intelligentsia. In: Essays on the Sociology of Culture, pp. 91-170. London: Routledge and Kegan Paul.

Merton, (1945 [1958]), The Role of the Intellectual in Public Bureaucracy. In: Social Theory and Social Structure, pp. 261-278. New York: Free Press.

Mills, C. Wright. The Powerless People: The Social Role of the Intellectual. Bulletin of the American Association of University Professors (1915-1955). Vol. 31, No. 2 (Summer, 1945), pp. 231-243.

Narayan, A. et al., (2018), Fair Progress? Economic Mobility Across Generations Around the World. Equity and Development. Washington, DC: World Bank. Accessible at: https://openknowledge.worldbank.org/handle/10986/28428 (accessed 1 July 2019).

Sapiro G., (2009)., Mod'eles d'intervention politique des intellectuels. Le cas franc, ais. Actes Rech. Sci. Soc. 176- 77:8-31

Schumpeter, J., (1943 [1994]), Capitalism, Socialism and Democracy. London and Routledge, NY.

Shils E., (1958 [1972]), The intellectuals and the powers: some perspectives for comparative analysis. In The Intellectuals and the Powers and Other Essays, pp. 3-22. IL: Univ. Chicago Press, Chicago.

Shils E., (1961), The Intellectual Between Tradition and Modernity: The Indian Situation. The Hague, Netherlands: Mouton Sowell, T. (2009), Intellectuals and Society. Basic Books.

Paris Statement (2018), A Europe we can believe in. Accessible at: https:// thetrueeurope.eu/ (accessed 1 July 2019).

Parsons, T., (1969)., "The intellectual": a social role category. In: P. Rieff (ed). On Intellectuals. Theoretical Studies, Case Studies. Garden City, NY: Anchor / Doubleday, pp. 3-26.

Posner, R., (2001), Public Intellectuals. A Study of Decline. Harvard University Press. 


\title{
BULGARIAN INTELLECTUALS IN THE MIRROR OF THEIR COLLECTIVE PUBLIC POSITIONS (2005-2019)
}

\begin{abstract}
The paper presents results of content analyses of 69 public collective positions of Bulgarian intellectuals, published in the internet media in the period of 2005-2019. The research question is what the image of the Bulgarian intellectuals in the mirror of their public collective positions is. Theoretical roots of the research are in the sociology of intellectuals and sociology of interventions. It is built on the works on intellectuals and intellectual field of the classic sociologists from XX century, as well as their new millennium successors. This study poses a number of questions for further research.
\end{abstract}

Key words: intellectuals, public intellectuals, petitions, open letters, ideas, values, symbolic power

JEL: Z180 